Michelle R. Garfinkel is an economist at the Federal Reserve Bank of St. Louis. Thomas A. Pollmann provided research assistance.

\title{
What Is an "Acceptable" Rate of Inflation?-A Review of the
}

\section{Issues}

"Our strategy continues to be centered on moving toward, and ultimately reaching, stable prices, that is, price levels sufficiently stable so that expectations of change do not become major factors in key economic decisions."

Alan Greenspan, Testimony to House Committee on Banking, Finance, and Urban Affairs, January 24, 1989

R tionary pressures, heightened by high rates of capacity utilization, have generated a large body of commentary concerning what level of inflation would be desirable or at least acceptable. While there appears to be a general consensus that a rise in the rate of inflation is not desirable, whether or not many would agree with Mr. Greenspan's statement above is not clear. Indeed, his statement makes a stronger suggestion that even the current rate of inflation is not acceptable. ${ }^{2}$

This article points out three central issues for determining what constitutes an "acceptable" rate of inflation. The first issue concerns the costs of inflation. The second issue is whether, despite these costs, inflation's benefits are suffi. ciently large to justify some positive rate of inflation. The final issue concerns the costs of reducing inflation. Even if there were convincing reasons for ultimately eliminating inflation, some analysts would argue that a positive inflation could be acceptable in the short-run; the optimal time path along which a long-run goal of zero inflation is achieved depends on the temporary costs of adjustment to reach that goal eventually.

\section{WVIAT ARE THE COSTS OR INTI A A TON?}

Examining the effects of inflation sheds light on why price stabilization is a primary objective of monetary policy. This section focuses on
1See, for example, Clark (1989) and Stein (1989).

2Mr. Greenspan expressed this view more clearly in his testimony to Congress in February 1989: ". . let the stress that the current rate of inflation, let alone an increase, is not acceptable, and our poicies are designed to reduce inflation in coming years." [Greenspan (1989), p. 274.] Elsewhere, he has been quoted as suggesting that the uftimate objective of the Fed is to eradicate inflation [Murray (1989)]. 


\section{Table 1}

\section{Some Effects of Inflation}

\section{Antcipared Inifation}

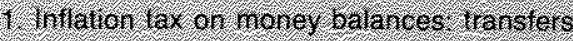

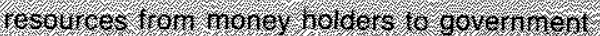
End edvces money dstiand.

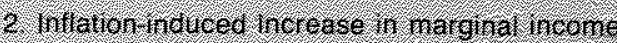

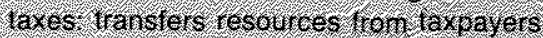
16 the government and tedices labor suphy.

3. Taxalon of rominal hterest incomo trans fer resowrees lon savers to the governiment and reouced sanings

4 interachon with tex neentines. reduces cost of bor rowing and increases debt thance.

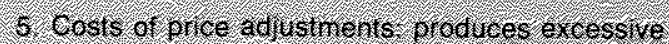
rolat me price varlabily and a hisallocalon olv resources

\section{Uianticipated hriston}

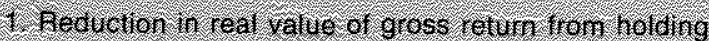
nomina Gebl transters resotrees $10 \mathrm{n}$ het

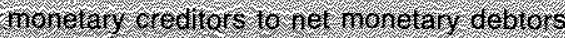

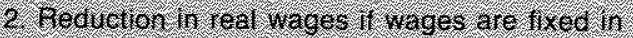
rominal terns ranstors resources fon tabor 10. indoyers

INation bincerainh

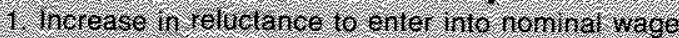

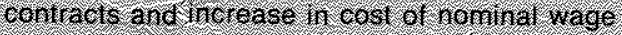

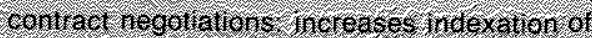

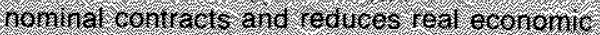
9romitis.

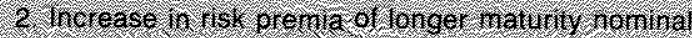

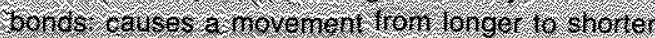
Ie m naturities and incterses the red cost of caplit:

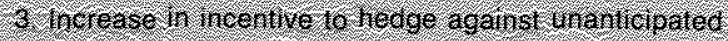

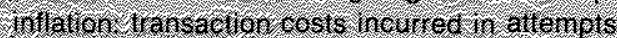

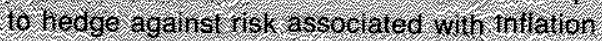

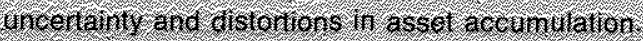

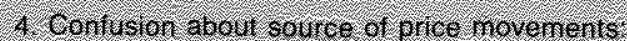

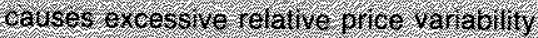
and a misaliocation or lestritces some of the relevant effects given existing institutional arrangements in the United States. ${ }^{3}$ These effects, as summarized in table 1 , are organized by their source: the effects arising from anticipated (or expected) inflation and those arising from unarticipated inflation (or the difference between actual inflation and expected inflation) and the associated uncertainty about future inflation.

\section{The Ef Inflation}

Much of modern macroeconomic research has been devoted to examining how expectations af. fect economic decisions. In contrast to the idea that only "surprises" or unanticipated events can have real effects, economic theory suggests that even fully anticipated inflation can distort economic decisions. These "distortions" are said to be the costs of anticipated inflation. A useful way to focus solely on the effects of anticipated inflation is to assume that the future sequence of changes in the general price level is known in advance. ${ }^{4}$

Anticipated inflation influences the allocation of resources in the economy primarily through two types of tax effects. First, inflation effectively imposes a tax on money balances equal to the
3For a more exhaustive list and detailed analysis of the effects of inflation, see Fischer and Modigliani (1978). Also, Kessel and Alchian (1962) provide a useful discussion of inflation's consequences. For a survey of the earlier literature concerning the theory of inflation, see Laidler and Parkin (1975).

${ }^{4}$ This assumption is made purely for expositional ease. When uncertainty is introduced in the discussion, the ef- fects of anticipated inflation mentioned in this section are simply added to those effects arising from the unanticipated component of inflation and those effects arising from uncertainty. It should be noted that the assumption of certainty does not preclede a variabie inflation rate. 
reduction of purchasing power of money holdings. For example, an individual holding $\$ 100$ throughout 1988 , when the inflation rate was around 4 percent, lost about $\$ 4$ in purchasing power. ${ }^{5}$

Since inflation imposes a tax on money balances, it reduces individuals' demand for money. ${ }^{6}$ Because individuals will attempt to economize on money holdings during periods of inflation by making extra trips to the bank or automatic teller machine, inflation is said to generate "shoe-leather costs." But the costs of the inflation tax are not merely the physical resources and time expended to avoid the infla. tion tax, as that term suggests. The total cost or the "gross burden" of the inflation tax more importantly includes the increase in the price paid to maintain real money balances and the value of lost services otherwise provided by money. Inflation, however, generates revenue to the government that indirectly accrues to individuals. The "excess burden" is the difference be tween the total costs and the government's revenues. Under some plausible assumptions, a rough estimate of this excess burden from a "small" inflation tax of 5 percent is about $\$ 13.4$ billion or about 0.3 percent of gross national product (GNP) per year. ${ }^{7}$

The excess burden of the inflation tax on money balances is only part of the total welfare cost associated with inflation. The second type of tax effect arises as anticipated inflation interacts with the structure of the existing income tax system, exacerbating the distortions contained therein. Since the progressive income tax system is not completely indexed against increases in the price level, inflation will subject individuals' incomes to higher average and mar. ginal tax rates. Even if wages fully adjust to in flation so that the real (before-tax) wage rate is approximately constant, an individual's real, after-tax income will decline. ${ }^{8}$

Although one would expect that, through the so-called "bracket-creep" effect, anticipated inflation would influence and distort individual's labor supply decisions, empirical evidence on the effects of marginal taxes suggests that an. ticipated inflation has little effect on aggregate
Inflation as measured by the consumer price index for all ufban consumers was 4.4 percent during 1988, while other measures indicate that inflation was between 3.0 percent and 4.5 percent. The current dollar loss of purchasing power of $\$ 100$ is calculated by the following equation: $P_{i+1}\left(\frac{100}{P_{i}}-\frac{100}{P_{i+1}}\right)$, where $P_{i}$ is the general price level in time . Since the rate of inflation, $\pi_{r}$, equals $\frac{P_{t+1}-P_{t}}{P_{1}}$, the loss in purchasing power in current dollar terms equals $100 \pi$. As noted below, the tax on money balances generates revenue to the government.

${ }^{5}$ Another way to see why inflation reduces the demand for money is by noting that inflation increases the opportunity cost of holding those balances. The opportunity cost is the revenue forgone by holding money rather than securities yielding a nomina interest rate, $A$. (The assumption that money does not yield interest is not important here. As argued by Tatom ( 1979 ), among others, even checkable deposits that pay interest are subject to the inflation tax.) Suppose, for example, that there is no expected future inflation. Then the nominal rate paid on a security is its real yield, r. An individual holding $\$ 100$ in cash balances for transaction services forgoes the real interest payment, $\$ 100 r$, that would have been obtained if he instead bought a $\$ 100$ bond. In this case, the opportunity cost of holding money balances is $r$ per dollar. Now suppose that inflation, $\pi$, in the next period is expected to be positive. The nominal yield on the bond $R$, will increase roughly by the amount of expected inflation to compensate lenders for the expected loss in purchasing power of the initial loan; the nominal yield will equal the real rate plus an expected inflation premium. (Strictly speaking, $R=(1+r)(1 \div \pi) \sim 1$.

Simply adding the real rate of interest and the rate of inflation will be a reasonable approximation provided that the product of the real rate of interest and the rate of inflation, $r \pi$, is of a small order of magnitude.) The higher nominal rate forgone by holding money implies that the opportunity cost of holding money has increased.

This estimate is intended to give only a rough order of magnitude of the excess burden of inflation. The estimate assumes that the current stock of money (M1) is about $\$ 780$ billion and that the interest elasticity of the demand for money is -15 . This latter assumption means that when the opportunity cost of holding money increases 1 percent, the quantity of money demanded falls .15 percent. Thus, assuming the real rate of interest is 3 percent, the demand for money would increase by 25 percent to $\$ 975$ billion if inflation were zero. It should be noted that the estimate of the welfare cost ignores the fact that total "tax" borne by the individual money holder does not go entirely to the government. Since the banking system receives part of the revenue from the inflation tax through money creation, the estimate above understates the excess burden. See Tatom $(1976,1979)$ and Fischer (1981b) for more detailed discussions of estimating the excess burden of the inflation tax on money balances.

In a preliminary study, Baye and Black (1988) table If, p. 480 , estimate that the "bracket-creep-induced inflation tax rate," defined as the difference between the rate of change in gross income necessary to keep utilty constant and the associated rate of change in consumption expenditures, ranges from 0.2 percent to 2.4 percent between 1972 and 1981. Furthermore, they find that changes in the tax code during this period, intended to mitigate the bracket-creep effect, were largely oftset by simultaneous increases in Social Security taxes (pp. 481-82). 
labor supply. ${ }^{9}$ Furthermore, to the extent that the current income tax system has become partially indexed by recent tax reform, the effects of inflation in terms of the bracket creep effect have been partially mitigated. ${ }^{10}$

Nonetheless, recent tax reform has not fully insulated individuals from the tax effects of anticipated inflation. Anticipated inflation produces an overstatement of interest income subject to taxation. The nominal interest rate required by lenders includes two components. The first component, $r$ is a payment to the lender for not consuming today and, hence, constitutes income. The second component, $\pi$, is a premium to compensate the lender for the anticipated lost purchasing power of the principal due to inflation. Because the latter component serves to preserve the value of the principal, it is not income in an economic sense. Yet, like income, it is taxed.

To see how an increase in anticipated inflation increases an individual's tax liability for a given before-tax real return, consider the following example. Suppose, first, that no inflation is expected and the marginal income tax rate is 25 percent. A one-year loan that yields a 3 percent (real) return to an individual before taxes generates an after-tax real return of 2.25 percent. If, instead, the anticipated rate of inflation were 2 percent, with the real interest rate on the one-year loan remaining at 3 percent, and the nominal yield rising to 5 percent the real rate of interest plus the rate of inflation that would be required when abstracting from tax considerations), then the after-tax real rate of return to the lender would fall to 1.75 percent. A rise in the anticipated inflation rate to 5 percent would erode the expected (and actual) return dramatically to 1 percent.

Lenders will demand a nominal return higher than the original real interest rate plus the rate of inflation to be compensated for the increased future tax kiability arising from an increase in anticipated inflation. In the example above, for the lender to supply the same dollar amount of loans as when expected inflation was zero, the same after-tax real return of 2.25 percent would be required; this, in turn, would require a rise in the nominal return from 3 percent to 9.67 percent when expected inflation rises to 5 percent. Hence, the nominal rate of interest must rise by more than the rate of inflation to induce the lender to forgo the same amount of current consumption. If, however, nominal interest rates did not rise enough to keep the after-tax real rate the same when inflation rises, savings would be reduced. It has been estimated that the distortionary effect of a 10 percent rate of inflation on savings over a 20-year period produces a total welfare loss itotal cost net of additional revenues to the government in present value terms) of about 7 percent of current savings or, assuming that savings is 10 percent of GNP, about 0.7 percent of current GNP. ${ }^{11}$

Tax incentives combined with anticipated inflation distort financial decisions. Because nominal interest payments on debt are taxdeductible and dividends are effectively taxed twice, anticipated inflation will induce corporations to finance an expansion of their operations by creating debt rather than issuing additional stock. If nominal interest rates do not adjust to anticipated inflation enough to maintain a fixed, after-tax real rate of return, then an increase in anticipated inflation can induce individuals to finance a greater proportion of their consumption and asset purchases with debt. ${ }^{12}$ This bias for debt finance, which increases with anticipated inflation, could be costly if, by increasing future debt obligation as a fraction of expected future cash flows, it increases the chances of future default.
SSee, for example, Hausman (1981), who finds that the taxinduce effects on wages do not significantly reduce aggregate labor supply. Inflation's effect on the marginal tax rate could similarly have an insignificant effect on labor supply.

10Tatom (1985) discusses the impact of the partial indexation of the income tax system on real tax liabilities. As discussed by Tatom, the currently used method of indexation does not fully mitigate the bracket creep effect because the indexation of tax brackets is calculated using past increases in the general price level. Furthermore, some deductions, credits and adjustments that can be made for tax purposes have maximum dollar limits or nominal ceilings that are not indexed. Even assuming a constant real income before taxes, an expected rise in the price level implies that a larger portion of real income will be subject to taxes. Without increasing the marginal tax rate, anticipated inflation increases the average tax tability.

11Fischer (1981b), p. 23. As he notes, however, the estimate is rough and could be as large as 2 percent to 3 percent of GNP under slightly different, although still plausible, assumptions.

${ }^{12}$ Even if nominal rates fuliy adjusted to increases in anticipated inflation so as to not affect the affer-tax real return, an increase in anticipated inflation decreases the cost of debt finance to firms provided that the corporate marginal tax rate exceeds the individual marginal tax rate. 
The impact of anticipated inflation on economic behavior is not restricted solely to inflation-induced tax effects. Specifically, by changing prices, some firms incur lump-sum or "menu" costs. Even if these costs are small, realworld price adjustments occur at discrete times rather than continuously. Assuming that price changes are not sychronized, anticipated inflation (and deflation) can generate relative price changes in the short run. Since these inflationinduced relative price changes do not reflect real, fundamental changes in the economy, they can create a misallocation of resources, resulting in a welfare loss in addition to the explicit costs of changing prices. ${ }^{13}$

\section{The Effects of Unanticipated Infla- ton and Uncertainty}

Unanticipated inflation also can result in a misallocation of resources. Its impact on individuals' behavior, however, is less obvious. In particular, although unanticipated inflation primarily redistributes wealth among people, it is the uncertainty associated with these possible future redistributions that distorts economic behavior. Before discussing these distortionary effects, this section focuses on the distributional effects of unanticipated inflation.

To examine the distributional effects, while initially abstracting from the effects of uncertain. ty per se, suppose there is a one-time shock to the level of inflation. The shock is temporary in the sense that, after one period, the rate of inflation will return to the previously expected time path. ${ }^{14}$ This unanticipated inflation influences the distribution of wealth through contracts that fix future nominal cash flows, especially debt contracts.

\footnotetext{
${ }^{13}$ Mankiw (1985) demonstrates that, in the presence of even small price adjustment costs, optimizing behavior by pricesetting firms can produce sticky prices that are inefficient from a social welfare perspective in a deflationary period. He shows, however, that sticky prices in an inflationary period could be more efficient than fully flexible prices. Since price-setting tirms produce at lower-than-sociallyoptimal levels, sticky prices in an inflationary period reduce the wedge between actual and socially optimal outpul levels.

14if the level of inflation were permanently increased above its previously expected and actual leve, but the possibility of a future shock were arbitrarily close to zero, the discussion to follow is virtually unchanged. It should be noted. however, that the discussion implicitly assumes that, when contracts are signed, individuals do not perceive the possibility of shock in the future. Hence, the discussion is about a counferfactual and can be misieading. Specifically, if individuals suspected that such a shock might occur
}

When debt contracts are fixed in nominal terms, the main effect of unanticipated inflation is to redistribute real wealth to net monetary debtors at the expense of net monetary creditors. ${ }^{1.5}$ Not suspecting the possibility of a divergence between actual and expected inflation, a lender would demand a rate of return that compensates him only for not consuming today and for the lost purchasing power of the initial borrowings due to anticipated inflation. When actual inflation exceeds anticipated inflation, the lender unexpectedly suffers a loss on his loan; the purchasing power of the return on the loan falls below that expected at the time the loan was made.

For example, suppose an individual, who expects zero inflation over the next period, $г$ quires a 5 percent nominal (and real) return next period in exchange for lending $\$ 100$ today. Regardless of next period's inflation, the lender will receive $\$ 105$ in the next period. If there is a 5 percent (unanticipated) inflation, then the purchasing power of the $\$ 105$ payment to the lender is identical to that of the $\$ 100$ lent. In this case, the real net return is zero.

Just as unanticipated inflation efodes the real purchasing power of the return from the loan, it reduces the real liability of the debtor. Along the same lines, if nominal wages specified in labor contracts are fixed for an interval of time, unanticipated inflation reduces an individual's real wage while increasing an employer's income net of the wage bill in real terms.

Although the redistribution of wealth due to unanticipated inflation is important to the individual before and after the fact, it is not easy to say anything meaningful about the welfare implications of the realized or ex post redistrib-

(with a positive probability), they would adjust their behavior, so that the terms of the contract reflect the possibility of a future shock. The implicit assumption is made for expositional purposes, and the possible ad. justments in behavior are discussed in turn.

15A net monetary creditor's (debtor's) holdings of fixed nominally denominated assets are greater (less) than his holdings of nominally denominated liabilties. See, for example, Kessel and Alchian (1962). Alchian and Kessel (1959) present evidence that the market value of equity of firms classified as net monetary creditors tends to fall during inflationary periods. The converse holds for net monetary debtors. 
utions. ${ }^{16}$ 'The losses due to unanticipated infla. tion are matched by others' gains, so that there is no net change in wealth associated with the redistribution. In an expected or ex ante sense, however, the possible (and arbitrary) redistributions have aggregate welfare implications, because they distort behavior, especially that of in. dividuals who dislike risk.

Uncertainty associated with inflation manifests itself quantitatively and qualitatively in both nominal and real contracts. In the presence of fixed nominal wage contracts, uncertainty associated with future inflation can depress the supply and demand for labor. As greater inflation uncertainty increases the difficulties and costs of forecasting futtre inflation, wage negotiations become more complex and costly. Consequently, without nominal wage indexation when future inflation becornes more uncertain, individuals and firms are less willing to lock themselves into fixed nominal contracts.

But the effects of inflation uncertainty will be partially alleviated as labor markets adjust. Greater uncertainty about future increases in the general price level gives risk-averse individuals and firms an incentive to increase the degree of indexation in wage contracts and to reduce the duration of the contract. The increased degree of indexation and the shortening of the length of the nominal contracts increases the responsiveness of nominal wages to unanticipated inflation. ${ }^{17}$ Nevertheless, a recent empirical study, which accounts for the greater wage indexation induced by greater inflation uncertainty, indicates that an increase in inflation uncertainty similar to that which occurred roughly between the 1960 s and the $1970 \mathrm{~s}$ would reduce growth in real GNP in the long term by approximately 2 percent. ${ }^{18}$

Inflation uncertainty also affects the demand and supply of nominally denominated debt of different maturities. Risk-averse lenders might be less willing to purchase a long-term nominal bond over short-term nominal bonds. As forecasting future inflation becomes more difficult with longer time horizons, the opportunity cost of holding a longer-term nominal bond is more uncertain. In addition, a given permanent unexpected movement in the rate of inflation will have a greater impact on the market value of the longer-term bond and, consequently, a greater impact on the realized rate of retum from selling that bond. To compensate lenders for taking on additional risk, the required nominal yield on a bond with a longer maturity will embody a greater risk premium.

The uncertainty associated with future inflation creates an element of uncertainty about real, future rates of return on all investments whose returns are not fixed in real terms. The more uncertain are the future rates of inflation, holding all else constant, the greater the risk premia for all bonds of any given maturity. ${ }^{19}$ As the required nominal yields on instruments of all maturities increase with greater inflation uncertainty, the cost of capital financed by nominal debt increases. Not all investments, however, are fixed in nominal terms. The riskaverse individual can hedge, at least partially, against unanticipated inflation by investing in projects or holding financial instruments whose actual and expected real returns are relatively

\footnotetext{
16Such a value judgment would depend on the specified social welfare function-in particular, the relative weights assigned to each individual's uttlity. Nonetheless, the decline in wealth experienced by some in a period of positive unanticipated inflation does not necessarily provide sufficient justification, in terms of a Pareto efficient criterion, for a "forced" transfer of resources to restore the initial distribution of wealth.

17 When the economy is subject to real as well as to nominat disturbances, however, complete wage indexation is not desirable. See Gray (1976) for example. Also, see Holland (1984b) for a more detailed discussion of the effects of inflation uncertainty on labor markets.

18Holland (1988), p. 478-80. This is a cumulative effect over a number of years (e.g. 2 to 6 years). In general, however, there is mixed evidence about the effects of inflation uncertainty on output growth. For example, Jansen (1989) finds that the conditional variance of inflation as a measure of inflation uncertainty has no significant impact on real output growth.
}

\begin{abstract}
19Taylor (1981), among others, finds a positive relation between the average rate of inflation and the variability of inflation across nations and through time. This stylized fact, however, does not imply any causal link between the two. Moreover, greater variability does not imply greater uncertainty. Nevertheless, preliminary evidence indicates that inflation variability is positively related to uncertainty, as measured by the variance of the forecast errors from survey data or from an econometric model for predicting future inflation, or as measured by the dispersion of inflationary expectations within a survey. But Jansen (1989) recently found no statistical relation between inflation and the conditional variance of inflation. See Taylor (1981) and Holand (1984a), who review the existing evidence on the relations between average infiation, the vartability of inflation and uncertainty.
\end{abstract}


independent of future rates of inflation, such as human capital, homes and corporate stocks. ${ }^{20}$

Even a complete hedge against unanticipated inflation would not eliminate the welfare costs of uncertainty, however. Substantial transaction costs can be incurred by those who attempt to eliminate the risk associated with future inflation from their portfolios. In any case, as individuals and firms attempt to hedge against unanticipated movements in the general price level, inflation uncertainty can distort asset accumulation and the aggregate allocation of resources. ${ }^{21}$

Another distorting feature of the uncertainty associated with price movements arises when information about the source of price movements is not available without costs. If information were costless to obtain, the appropriate response to a given increase in prices is clear. For example, an unanticipated temporary increase in observed prices correctly attributed to monetary policy la nominal factor), rather than to an increase in demand for some goods relative to others (a real factor), would not alter the decisions of producers in the absence of nominal rigidities. If it is costly, however, to distinguish between general price movements produced by nominal factors from those created by real factors, price movements will be "noisy." Confusion about the source of a given price movement and the appropriate response will produce excessive relative price variability, resulting in a misallocation of resources. ${ }^{22}$

\section{WIVIV NOT A ZERO PATE OE 其N}

While any positive inflation has a large number of distortionary effects, a zero inflation rate might not necessarily be desirable-even in the long run. First, the various measures of inflation (for example, the consumer price index and the GNP implicit price deflator) do not control perfectly for quality improvement of products over time. To the extent that the lower and higher quality versions of goods are treated as comparable, the difference in their prices will be measured as inflation; the resulting measure will tend to overstate the actual inflation rate. Given this positive bias in inflation measures, it has been suggested that a 2 percent inflation rate measured by the usual price indexes would be associated with roughly stable prices ${ }^{23}$ Moreover, some would contend that inflation also has some important benefits like providing a cheaper source of government revenue or creating higher output and employment, so that the long-run desirable rate of inflation is not zero, but positive.

\section{Optimal Tagation}

Some have argued that inflation is required for optimal taxation. ${ }^{24}$ The inflation tax provides
20While homes appear to be good hedges against expected and unexpected inflation, the evidence for human capital is inconclusive, at least for the long run. Moreover, a puzzling negative relation between stock returns and expected as well as unexpected inflation has been widely documented, but not resolved. See, for example, Fama and Schwert (1977).

${ }^{21}$ See Jaffee and Kleiman (1977) for a more detailed discussion of the effects of inflation uncertainty on the altocation of resources.

${ }^{22}$ To be sure, relative price variability need not be a cost. To the extent that relative price movements signal real distur bances to the economy, those movements contain important information facilizating an efficient allocation of resources. Fischer (198ta) provides a summary of competing approaches to explaining the relation between the average inflation rate and relative price variability. Taylor (1981) and Fischer (1981b) do not find evidence indicating a causal relation between inflation and variability of relative prices. Rather, Taylor (198\$) and Fischer (1981a) find evidence consistent with the notion that the positive relations between average inflation, the variability of inflation and relative price variability in the 1970 s have been driven by supply shocks (for example, energy and food shocks). Taylor (1981) also finds that accommodative monetary policies aiming to stabilize output and employment in light of real disturbances to the economy contributed in a large part to the increased variability of infla tion in the 1970s. Furthermore, Fischer (1981a) concludes that policy shocks that could have created confusion about the source of price movements do not appear to be associated with lower aggregate economic activity.

23Friedman (1969), p. 47. According to Friedman (1969), however, a negative inflation rate (about 2 percent deflation) correctly measured would be optimal. In this case, a zero inflation rate, as measured by the various price indices would be a desirable target. (See Alchian and Klein (1973) for a critical assessment of the appropriateness of the price indexes for policy.)

${ }^{24}$ See, for example, Phelps (1973). The government's revenue from the production of money is the nominal rate of interest times the stock of the monetary base (total reserves plus currency). Using the lact that the ratio of the monetary base to the money stock (M1) is about 40 percent and assuming that the real interest rate is about 3 percent, the revenue with a 5 percent inflation tax on a stock of $M 1$ of $\$ 780$ billion is about $\$ 25$ billion per year in current doliar terms. The inflation tax alone generates $\$ 15.6$ billion per year. It is important to note that unanticipated inflation implicitly generates additional revenue to the government (a net monetary debtor) through its effect on the reat value of public debt. By reducing the purchas" ing power of interest payments on outstanding debt, unanficipated inflation lowers the real liablity of the government and the amount of revenue to be raised through income taxes. 
the government an alternative source of revenue to other explicit and distorting taxes-for example, income taxes. ${ }^{25}$ The theory of optimal taxation suggests that, to finance a given level of public expenditures, the government should trade off the costs of distortions arising from in. flation against those arising from other taxes. ${ }^{26}$ From this perspective, the optimal inflation tax rate equates the marginal cost per dollar of revenue from the inflation tax and from other distorting taxes.

Recent empirical evidence on the marginal costs of the inflation tax and other laxes, however, casts doubt on the relevance of the optimal taxation theory to justify a positive rate of inflation. These studies suggest that the marginal cost per dollar revenue of the inflation tax at any positive rate of inflation exceeds that for alternative taxes set at plausible rates. ${ }^{27}$ In other words, inflation does not necessarily provide a cheaper source of government revenue. Furthermore, the interaction between inflation and the distortions produced by the tax system suggests that the marginal cost of income taxes could be positively related to the rate of infla* tion; thus, lowering the inflation tax not only would reduce the welfare losses associated with the inflation tax, but make income taxation a cheaper source of government revenue. ${ }^{28}$

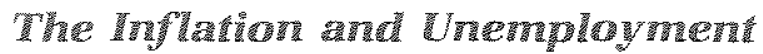 Treded}

The older argument used to justify positive inflation hinges on the so-called Phillips curve trade-off between inflation and unemployment. Figure 1, which depicts the apparent trade-off that emerged in the 1960s, could be interpreted as suggesting that, by tolerating a higher level of inflation, society could benefit from lower levels of unemployment.

One possible story behind such an interpreta tion is that an expansionary monetary policy that increases the general price level can increase output if nominal wages are relatively fixed. With fixed nominal wages, a rise in infla. tion can induce firms to increase output. This incentive arises because the firm's marginal profit-that is, the change in real revenues net of the change in the real wage bill realized by expanding output-increases with unanticipated inflation. If nominal wages were not fixed, they would adjust quickly to the increase in prices to maintain a given real wage rate; output and un. employment would be essentially independent of inflation. But, according to the trade-off view, the existence of nominal wage contracts means that, by generating inflation, the government can decrease the rate of unemployment and thereby enhance social welfare.

The possibility of exploiting the trade-off between inflation and unemployment with monetary policy, however, depends on the way in which inflationary expectations are formed and incorporated into nominal wages. If inflation is correctly anticipated and incorporated into wage contracts, then real output will be independent of inflation in the long run. Even if the government were to generate inflation un.

\footnotetext{
251f there were non-distorting taxes, then the excess burden of the inflation tax discussed above would render inflation an "inefficient" tax. But, in the absence of non-distorting taxes as a source of revenue to the government, the optimal rate of inflation could be positive. Browning (1987), table $1, p .16$, estimates that in 1984 the total welfare cost associated with the distortionary effects of the labor tax ranged from $\$ 55.9$ billion to $\$ 212.6$ bitlion under various assumptions. As a percentage of tax revenues from labor, the welfare loss ranged from 7.5 percent to 28.5 percent, well below the inflation-induced welfare loss as a percentage of revenues from the inflation tax (about 86 percent).

26in recent studies, Mankiw (1987) and Poterba and Rotemberg (1988) test the implications of the hypothesis that the government optimally trades off the distortions from explicit income taxes and inflation. While Mankiw finds preliminary evidence supporting the hypothesis for the United States, Poterba and Rotemberg, who look at different nations, do not find conclusive evidence. That the hypothesis is not fully supported by the data might be a result of the maintained assumption that the distortionary effects of the explicit tax system are independent of the distortionary effects of the inflation tax. Given the discussion above, this assumption seems inappropriate.
}

27For example, Tatom (1976), p. 20, shows that marginal cost per dollar revenue of the inflation tax, assuming that the elasticity of demand for money is -.15 , is 44 percent. This estimate is not conctitional on the inflation rate, but it is highly sensitive to the assumed elasticity of demand for money. For example, an elasticity of -.25 would imply a marginal cost of 83.33 percent. Browning (1987), table 2, p. 21, shows that the marginal welfare cost from taxes on labor earnings ranges from 9.9 percent to 33.2 percent under the assumption that labor supply is not highly responsive to the marginal income tax rate (see footnote 9 ).

28It should be noted, however, that since the marginal cost of taxes on labor earnings is positively related to the marginal tax rate, the theory of optimal taxation in light of the evidence on marginal welfare costs does not necessarily imply a zero rate of inflation. Nevertheless, if the marginal cost of the inflation tax were positively related to inflation, the optimal rate of inflation would more likely be zero. 


\section{Figure 1 \\ The Inflation-Unemployment Trade-off}

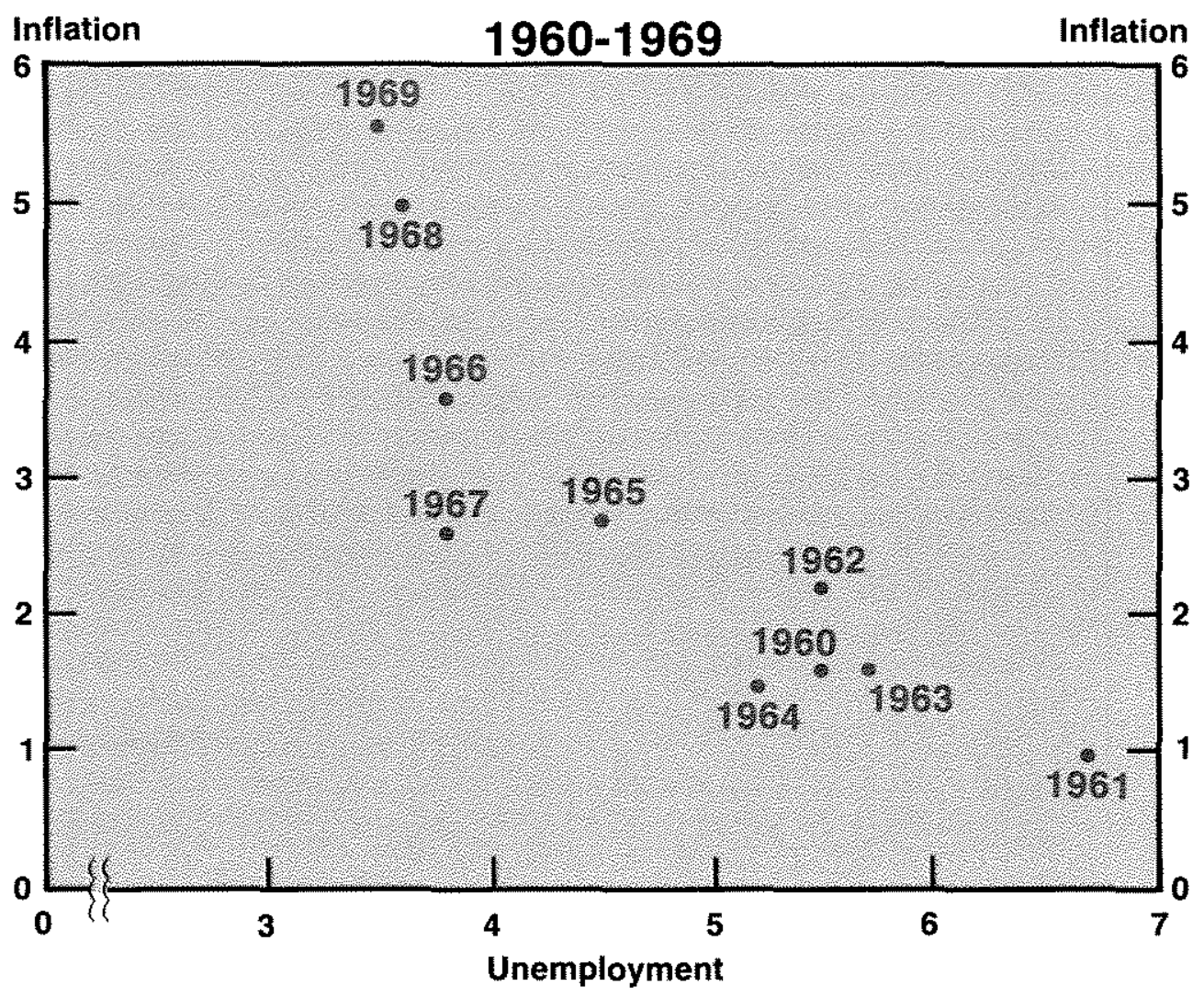

expectedly, the increase in output and decrease in unemployment would only be transitory. Subsequent wage changes would restore the original level of the real wage. As a consequence, the original profit rate would be restored, with output and unemployment returning to their original equilibrium or "natural" levels; the trade-off between unemployment and inflation would not exist in the long run. ${ }^{39}$

Indeed, figure 2, which plots the combinations of unemployment and inflation in the 1970s and the 1980s, does not support the existence of a long-run trade-off. While a short-run trade-off might exist, whether or not it is operative for the purpose of enhancing social welfare is un- clear. Attempts to "fool" individuals systematically, by continuously creating surprise inflation so as to exploit the short-run trade-off, would not improve the welfare of all individuals because, although some individuals experience unexpected wealth gains, others suffer wealth losses. In addition, attempts to repeatedly fool individuals would increase the costs associated with inflation due to increased inflation uncertainty.

Moreover, as individuals and firms adjust to the higher inflation uncertainty, the trade-off becomes less favorable, because greater inflation uncertainty increases incentives for indexation. With greater wage indexation, a given

in the long run (a vertical Phillips curve) is known as the "Natural Rate Hypothesis."
29 See Fischer (1977), for example. The notion that real output and employment are independent of the inflation rate 


\section{Figure 2}

\section{The Inflation-Unemployment "Trade-off"}

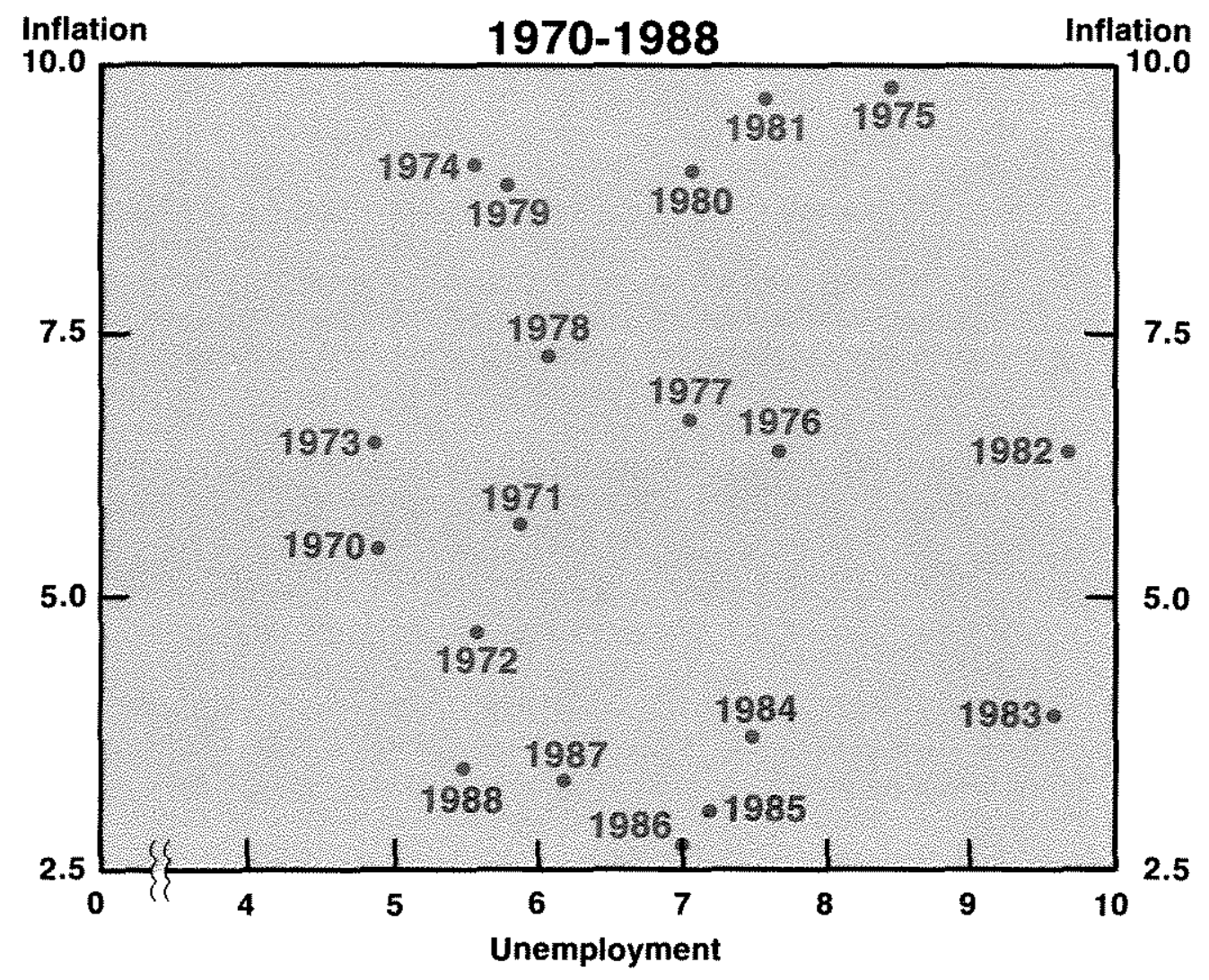

amount of surprise inflation will have a smaller transitory effect on output and employment as nominal wages become more responsive to actual inflation. Accordingly, the trade-off becomes steeper. If attempts to exploit the tradeoff also increases average inflation, the trade-off shifts outward, so that a given rate of inflation will be associated with a higher rate of unemployment.

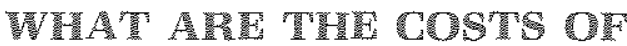 PEDUCWNG TNWLATION?}

The suggested benefits of inflation seem hardIy compelling to justify any positive, sustained inflation. The long-run desirability of achieving stable prices, however, does not necessarily mean that the current rate of inflation is unac- ceptable. Specifically, the latter discussion suggests that policies to reduce inflation and ultimately achieve the long-run desirable inflation rate can be costly. That is, any short-run trade. off between inflation and unemployment implies that anti-inflationary policies will produce temporary increases in unemployment.

\section{Are The Costs Too IIIIh?}

Table 2 shows the inflation rate, as measured by the GNP implicit price deflator, and the civilian unemployment rate; it indicates that the large reduction in inflation from 1979 to 1988 was accompanied by significantly large rates of unemployment. These observed high rates of unemployment, however, can overstate the costs of the anti-inflationary policy. Regardless of the current inflation rate or its prospective 


\section{Table 2}

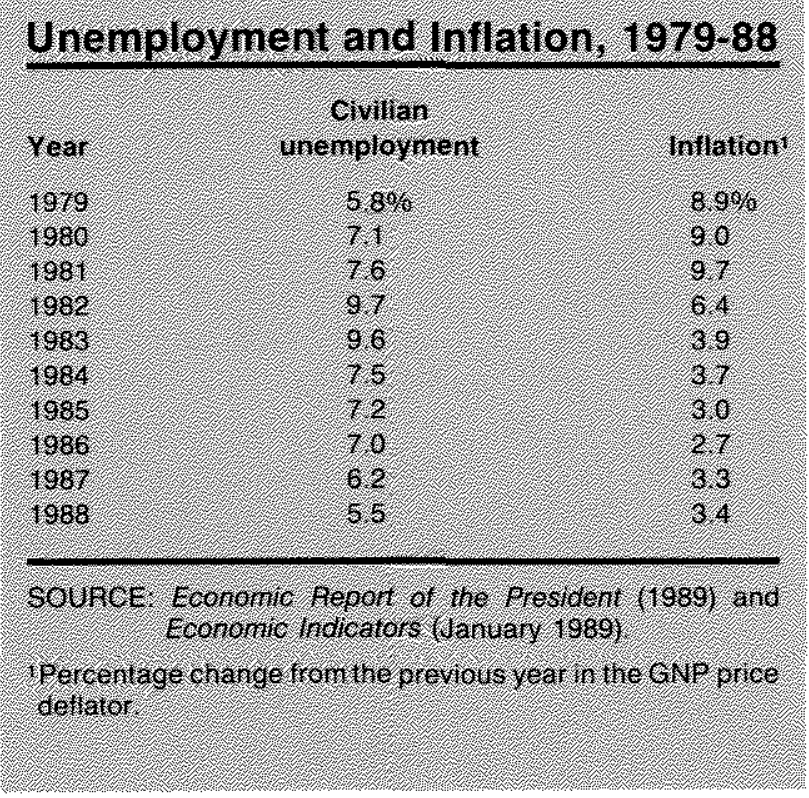

path, temporary unemployment is an efficient response to fundamental changes in the economy, as individuals search for new jobs. Consequently, the "natural" rate of unemployment (the rate of unemployment consistent with a steady inflationl can be positive. It has been estimated that, assuming the natural rate of unemployment is 6 percent, the decline in infla tion from 9 percent in 1980 to 3.2 percent in the middle of 1987 was associated with about 2.4 percentage points of "excess" unemployment per percentage-point reduction in inflation. ${ }^{30}$

Similarly constructed estimates have been used to suggest that reducing inflation is unacceptable on efficiency grounds:

The damage that high unemployment does to economic efficiency is enormous and inadequately appreciated. By contrast, the harm that inflation inflicts on the economy is often exaggerated; and those costs which are not mythical can be minimized or even eliminated by indexing. Hard.

headed devotion to the principle of efficiency thus argues for worrying less about inflation and running a high-pressure economy in which jobs are plentiful. ${ }^{31}$

By definition, excess unemployment is ineffi. cient, because it implies that resources, otherwise available to increase consumption opportunities, have been wasted. But excess unemployment is only a transitional cost as the economy adjusts to the long-run desirable inflation rate. When the inflation goal is finally achieved and sustained, the excess unemployment will disappear. In contrast, the welfare costs associated with inflation are incurred indefinitely-that is, each year in which the economy's institutional features (for example, the explicit tax system) make the distortionary effects of inflation discussed above relevant. ${ }^{32}$

\section{The Optinnal Time prath of Reducing Inflation}

Among the important questions that policy. makers must face is the timing of anti-inflationary policy actions to reach the long-run desirable inflation rate. Given the initial inflation rate, the speed with which the desirable inflation rate is reached partly determines the cost of that policy.

One recent study shows that there are large differences in the costs of policies that vary with respect to their timing ${ }^{33}$. On the basis of various models, this study calculates the costs of several policies to bring inflation from 7.5 percent to zero. The costs of the policies are estimated in terms of output losses using a relationship known as Okun's law that translates each percentage point of excess unemployment into a 3.2 percent reduction in real output. For example, employing a Phillips curve model, this study

\footnotetext{
30Friedman (1988), p. 66. Each percentage point of unemployment above the natural rate (or that in a "fully employed" economy, with a steady inflation rate) con. stitutes a percentage point of "excess" unemployment. Of course, because the natural rate of unemployment is not observed and is subject to change during the evolution of the economy subject to permanent and transitory real shocks, one could argue that Friedman's esimate understates (or overstates, for that matter) the welfare loss associated with the reduction of inflation in the 1980s.

31 Binder (1987), p. 65.

${ }^{32}$ Of course, not all anti-inflationary policies can be justified Rather, without a careful evaluation of the costs and beneftits of reducing inflation, a monetary policy that pro-
}

duces an inflation above (or below) the optimal rate does not easily follow from an efficiency criterion. As pointed out by Meyer and Rasche (1980, p. 14), among others, however, if the benefits from eliminating inflation (or identically, the costs of sustaining inflation) increase at the same rate of real potential output, then any antiinflationary policy would be justified, irrespective of the policy"s costs, provided that the costs are finite and that the initial gain from such a policy is positive.

${ }^{3}$ Meyer and Rasche (1980). 
found that a gradual policy to eliminate inflation over a 23-year period could generate a discounted cumulative output loss of $\$ 1$ trillion (in 1972 terms), whereas a policy that reached the inflation goal in 11 years could result in a discounted cumulative output loss of $\$ 1.5$ trillion. ${ }^{34}$

The relation between the time path and the costs of the policy depends on the dynamic relation between unemployment and inflation. In addition to the degree to which the economy is indexed, this dynamic relation depends on the credibility of the anti-inflationary policy and expectations about future inflation. If, as assumed in the Phillips curve model, expectations depend on past inflation, a given inflation-reducing policy will be more costly; with nominal rigidities in the economy and a sluggish adjustment of expectations, the short-term trade-off between inflation and unemployment can be large. To achieve a specific reduction in inflation over a given time span can require higher levels of unemployment and greater output losses. If inflationary expectations are forward-looking and the policy is credible, however, the link between inflation and unemployment is weaker; in this case, unemployment is less responsive to movements in inflation. Accordingly, credible anti-inflationary policies will be less costly in terms of output losses than incredible ones. ${ }^{35}$

The time path of the anti-inflationary policy is also important because it determines the speed with which the gains from such a policy are realized fully. For example, a gradual policy that eliminates inflation over 50 years might not generate significant output losses, but the present discounted value of the benefits from that policy could be infinitesimally small.

\section{GONGWUSON}

Analyses of the acceptability of any particular positive inflation should start by asking what is the optimal rate of inflation. In reviewing the various effects and costs of inflation, this article questions the validity of the notion that any positive inflation could be desirable as a long. run phenomenon. The surprisingly large number of distortionary effects resulting from inflation weakens the possible justifications for sustained positive inflation.

The long-run desirability of zero inflation need not imply, however, that a positive rate of inflation is never acceptable for any period. The transitional costs of reducing inflation over a short period could be considerably large relative to the benefits of quickly eradicating inflation. But the costs of fighting the current inflation do not preclude the desirability of an anti-inflationary policy, either. Indeed, the steady reduction in monetary aggregate growth since 1987 (measured by M1, M2 or the adjusted monetary basel suggests that the trade-off has been faced, at least implicitly. In any case, the acceptability of an inflation in excess of the long-run desirable rate depends on the appropriately measured net benefits of alternative paths to achieve the ultimate inflation goal.

\section{PEA}

Alchian, Armen $A_{1,}$ and Reuben A. Kessel. "Redistribution of Wealth Through Inflation," Science (September 4, 1959), pp. 535-39.

Alchian, Armen A., and Benjamin Klein. "On a Correct Measure of Inflation," Journal of Money, Credit and Banking (Part 1, February 1973), pp. 173-81.

Baye, Michael R., and Dan A. Black. "The Microeconomic Foundations of Measuring Bracket Creep and Other Tax Changes," Economic Inquiry (July 1988), pp. 471-84.

Blinder, Alan S. Hard Heads, Soft Hearts: Tough-Minded Economics for a Just Society (Addison-Wesley, 1987).

Browning, Edgar $K$. "On the Marginal Welfare Cost of Taxation," American Economic Review (March 1987), pp. 11-23.

Clark, Lindiey H. Jt. "Why Don't We Aim for Zero Inflation?" Wall Street Journal, February $9,1989$.

Cukierman, Alex. "Central Bank Behavior and Credibility: Some Recent Theoretical Developments," this Review (May 1986), pp. 5-17.

Fama, Eugene F., and G. William Schwert. "Asset Returns and Inflation," Journal of Financial Economics (November 1977 ), pp. 115-46.

Fischer, Stanley. "Relative Shocks, Relative Price Variability, and Inflation," Brookings Papers on Economic Activity (1981a), pp. 381-431.

\footnotetext{
${ }^{34}$ Ibid., pp.7-8.

${ }^{35}$ Taylor (1983) shows that even if ovelapping wage contracts temporarily fix nominal wages, a policy that gradualIy reduces intlation can be relatively costless provided that expectations about future inflation are rationally formed and everyone believes that the policy will actually be implemented. See Cukierman (1986) and references cited. therein for analyses of the institutional and economic fac-
}

tors that tend to detract from the credibility of ant:inflationary policies. These analyses suggest that, without a perfect resolution of the credibility problem, the economy is likely to be characterized by an "inflationary bias." Fischer and Summers (1989) show how by decreasing the marginal costs of inflation, the government, recognizing the importance of its reputation, can reduce that bias. Without reputational considerations, however, reducing the costs of inflation can increase the inflationary bias. 
"Towards an Understanding of the Costs of Inflation: II," in Kark Brumner and Allan H. Meltzer, eds., The Costs and Consequences of inflation, Carnegie-Rochester Conference Series on Public Policy (North-Holland, Autumn 1981b), pp. 5-42.

"Long-Term Contracts, Rational Expectations, and the Optimal Money Supply Rule," Journal of Political Economy (February 1977), pp. 191-206.

Fischer, Stanley, and Franco Modigliani. "Towards an Under. standing of the Real Effects and Costs of Inflation," Weltwirtschaftiches Archiv (Band 114, 1978), pp. 810-33.

Fischer, Stanley, and Lawrence $H$. Summers. "Should Governments Leam to Live With Inflation?" American Economic Review (May 1989), pp. 382-87.

Friedman, Benjamin M. "Lessons on Monetary Policy from the 1980s:" Journal of Economic Perspectives (Summer 1988), pp. 5172 .

Friedman, Milton. "The Optimum Quantity of Money," The Optimum Quantity of Money and Other Essays (Aldine, 1969), pp. $1-50$.

Gray, Jo Anna. "Wage Indexation: A Macroeconomic Approach," Journal of Monetary Economics (April 1976), pp. 221-35.

Greenspan, Alan. "1989 Monetary Policy Objectives," Testimony to the Congress (February 21, 1989) in Federal Reserve Bulletin (April 1989), pp. 272-77.

Hausman, Jerry A. "Labor Supply," in Henry J. Aaron and Joseph A. Pechman, eds., How Taxes Affect Economic Behavior (Brookings Institution, 1981), pp. 27-72.

Holland, A. Steven. "Indexation and the Effect of inflation Uncertainty on Real GNP," Journal of Business (October 1988), pp. 473-84.

"Does Higher Inflation Lead to More Uncertain Inflation?" this Review (February 1984a), pp. 15-26.

"The Impact of Inflation Uncertainty on the Labor Market," this Review (August/September 1984b) pp. 21-28.

Jaffee, Dwight $M$, and Ephraim Kleiman. "The Welfare Implications of Uneven Infation," in Erik Lundberg, ed., Inflation Theory and Anti-Inflation Policy (Macmillan, 1977), pp. 285-307.

Jansen, Dennis W. "Does Inflation Uncertainty Affect Output Growth? Further Evidence," this Review (July/August 1989), pp. 43-54.
Kessel, Reuben A., and Afmen A. Alchian. "Effects of Intlation," Journal of Political Economy (December 1962), pp. 521-37.

Laidler, David E., and Michael Parkin. "Inflation: A Survey," Economic Journal (December 1975), pp. 741-809.

Mankiw, N. Gregory. "The Optimal Collection of Seigniorage: Theory and Evidence," Journal of Monetary Economics (September 1987), pp. 327441.

"Small Menu Costs and Large Business Cycles: A Macroeconomic Model of Monopoly," Quarterly Joumal of Economics (May 1985), pp. 529-37.

Meyer, Laurence $H$, and Robert $H$. Rasche. "On the Costs and Benefits of Anti-Inflation Policies," this Review (February 1980), pp. 3-14.

Murray, Alan. "Fed's Goal is to Cut Inflation to Zero, Greenspan Says," Wall Street Journal, March 28, 1989.

Phelps, Edmund S. "Inflation in the Theory of Public Finance," Swedish Journal of Economics (March 1973), pp. 67.82

Poterba, James M., and Julio J. Rotemberg. "Inflation and Taxation with Optimizing Governments," National Bureau of Economic Research Working Papers Series, 2567 (April 1988).

Stein, Herbert. "Inflation is Here, Still," Wall Street Journal, March 6, 1989

Tatom, John A. "Federal Income Tax Reforn in 1985: Indexation," this Review (February 1985), pp. 5-12.

"The Marginal Welfare Cost of the Revenue From Money Creation and the 'Optimal' Rate of Inflation," The Manchester School (December 1979), pp.359-68.

"The Welfare Cost of Inflation," this Review (November 1976), pp. 9-22.

Taylor, John B. "Union Wage Settlements During a Disinflation," American Economic Review (December 1983). pp. $981-93$

"On the Relation Between the Variability of Intation and the Average Inftation Rate," in Karl Brunner and Allan $\mathrm{H}$. Meltzer, eds., The Costs and Consequences of inflation, Carnegie-Rochester Conference Series on Public Policy (North-Holland, Autumn 1981), pp. $57-86$. 